\title{
A Review of the HIV-infected Homeless Sub-population at the Centre for HIV/AIDS Research, Education and Services, Department of Medicine, University Hospital of the West Indies
}

G Barrow ${ }^{1}$, N Clare-Pascoe 2 , A Bahadur ${ }^{3}$, U Atkinson ${ }^{4}$, C Browne $^{4}$, TR Clarke ${ }^{2}$, EN Barton ${ }^{2}$

\begin{abstract}
Objective: The twin epidemics of HIV and homelessness present several challenging aspects to the development of programmes for the provision of treatment and care. This paper describes the characteristics of this population being managed by a collaborative effort between the Centre for HIV/AIDS Research, Education and Services, Department of Medicine, University Hospital of the West Indies and the National Council on Drug Abuse.

Subjects and Methods: A retrospective descriptive study was conducted via review of patients' medical files. Demographic and clinical data of the HIV-infected homeless population were summarized, highlighting issues related to the provision of care, rates of antiretroviral therapy (ART) uptake and subsequent adherence to treatment and known factors associated with HIV transmission.

Results: $A$ total of 12 cases were included in the analysis. There was an average age of 38.0 years (IQR $32.5-49.25)$ with the majority being female, nine (75.0\%). Late stage diagnosis was a common feature. The majority of cases were eligible for ART on first contact, with CD4 counts on average being 284.4 (95\% CI 10.9.0, 459.8). Significant risk factors for HIV transmission were also identified as all cases reported being sexual active with limited condom use reported and high reported numbers of lifetime partners, 30 (IQR 25.0-100.0). Other factors identified include eight (66.6\%) cases reporting sexually transmitted infection (STI) symptoms, 10 (83.3\%) reporting substance abuse and nine (75.0\%) reporting sex work.

Conclusion: The implementation of combination interventions providing a comprehensive package of services that address the multitude of issues facing the HIV-infected homeless population is required in order to appropriately manage this population.
\end{abstract}

Keywords: HIV, homeless, Jamaica

\section{Una Revisión de la Subpoblación sin Hogar de Infectados por el VIH en el Centro para la Investigación, Educación y Servicios del VIH/SIDA, del Departamento de Medicina del Hospital Universitario de West Indies}

\author{
G Barrow ${ }^{1}$, N Clare-Pascoe ${ }^{2}$, A Bahadur ${ }^{3}$, U Atkinson ${ }^{4}$, C Browne $^{4}$, TR Clarke ${ }^{2}$, EN Barton ${ }^{2}$
}

\begin{abstract}
RESUMEN
Objetivo: Las epidemias gemelas del VIH y las personas sin hogar, presentan varios aspectos desafiantes para el desarrollo de programas que ofrecen atención y tratamiento. Este trabajo describe las características de esta población, y su manejo como parte de un esfuerzo de colaboración entre el Centro para la investigación, educación y servicios del VIH/SIDA, del Departamento de Medicina del Hospital Universitario de West Indies, y el Consejo Nacional para el Abuso de Drogas.

Sujetos y métodos: Se realizó un estudio descriptivo retrospectivo mediante revisión de expedientes médicos de los pacientes. Se resumieron los datos clínicos y demográficos de la población sin hogar infectada por el VIH, destacando las cuestiones relacionadas con la prestación de asistencia, las tasas
\end{abstract}

From: ${ }^{1}$ Centre for HIV/AIDS Research, Education and Services, University Hospital of the West Indies, Kingston 7, Jamaica, ${ }^{2}$ Department of Medicine, The University of the West Indies, Kingston 7, Jamaica, ${ }^{3}$ Faculty of Medical Sciences, The University of the West Indies, St Augustine, Trinidad and

Tobago and ${ }^{4}$ National Council on Drug Abuse, Jamaica.
Correspondence: Dr G Barrow, Centre for HIV/AIDS Research, Education and Services, Department of Medicine, University Hospital of the West Indies, Kingston 7, Jamaica. E-mail: Geoffrey.barrow@uwimona.edu.jm 
de adopción de terapia antirretroviral (TAR), y la posterior adherencia al tratamiento, además de factores conocidos, asociados con la transmisión del VIH.

Resultados: Un total de 12 casos se incluyeron en el análisis. La edad promedio fue de 38.0 años (IQR 32.5-49.25), siendo mujeres la mayoría, 9 (75.0\%). El diagnóstico en etapa tardía fue una característica común. La mayoría de los casos fueron elegibles para TAR desde el primer contacto, con conteos CD4 de 284.4 (95\% CI 10.9.0, 459.8) como promedio. También se identificaron factores de riesgo significativos para la transmisión del VIH, ya que todos los casos reportaron actividad sexual con un uso limitado de condón, y un gran número de parejas sexuales durante toda la vida, 30 (IQR 25.0-100.0). Otros factores identificados incluyen $8(66,6 \%)$ casos que reportaron síntomas de infección de transmisión sexual (ITS), 10 (83,3\%) que reportaron abuso de sustancias, y 9 (75.0\%) que reportaron trabajo sexual.

Conclusión: Se requiere la implementación de intervenciones de combinación que ofrezcan un paquete integral de servicios que respondan a los numerosos problemas que enfrenta la población sin hogar infectada por VIH, a fin de tratar adecuadamente a esta población.

Palabras claves: VIH, personas sin hogar, Jamaica

West Indian Med J 2013; 62 (4): 338

\section{INTRODUCTION}

The twin epidemics of HIV and homelessness have many cross-cutting similarities, creating a complex interplay of cause of effect. The psychosocial impacts of HIV have been well documented (1) and are considerable on the various components of health and wellness as defined by the World Health Organization [WHO] (2). These are often further complicated by the effects of co-morbid mental health disease and substance abuse. Thus, the creation of an appropriate programme to address the needs of this population utilizing conventional models of medical management will not adequately respond to the complexities of this population. Strategies designed for the provision of care to this population require a comprehensive approach, involving a myriad of services, including medical, psychological and social support. One of the initial obstacles to the provision of services to this essentially nomadic population is continuous access.

Homelessness in Jamaica continues to affect people of all genders and a variety of ages. In 2009, data from the Kingston and St Andrew area of Jamaica estimated 2000 homeless persons, defined as persons residing in places not meant for human habitation and those in transitional homes. An overall HIV prevalence of $12 \%$ was identified, with $34 \%$ prevalence in females and $9 \%$ in males (3). Using a testretest methodology, the 2011 data indicated a rapidly growing population with an HIV incidence of $6.25 \%$ (4). High rates of substance abuse were also described in this subpopulation, with $59 \%$ of homeless persons reported using one or more substances. Sexually transmitted infections (STIs) have been reported at high rates in persons reporting substance use in Jamaica. One study in 2001 reported a prevalence of $6 \%$ for syphilis in persons presenting for substance abuse treatment (5). In an attempt to address these many issues, "Tek It To Dem", a project by the National Council on Drug Abuse (NCDA), in collaboration with the Department of Medicine's sub-unit, the Centre for HIV/AIDS Research, Education and Services (CHARES) located at the University Hospital of the West Indies (UHWI), expanded their outreach intervention for the homeless population to offer HIV treatment and care to this high-risk group in 2011. This paper provides superficial insight into the dynamics and challenges faced when providing services to the HIV-positive homeless population over a one-year period following the project's inception.

\section{SUBJECTS AND METHODS}

A retrospective descriptive review was conducted for the period August 2011 to December 2012 at CHARES, Department of Medicine, UHWI. Data were collected via review of patients' medical files using data extraction sheets. In July 2011, the Department of Medicine and the National Council on Drug Abuse embarked on a collaborative intervention to provide HIV treatment and care to the HIV-infected homeless population enrolled in their "Tek It To Dem" project. All analysis was conducted using SPSS version 17.0.

\section{RESULTS}

A total of 13 participants were included in the collaborative project; however, for one participant, deceased, data were not available. Of the 12 reported cases, there were nine females and three males with a median age of 38.0 years (IQR $32.5-$ 49.25). Since 2009, a median of 4.5 (IQR 1.0 - 7.7) visits per case was recorded with three cases having only one visit (Table 1).

Self-reported sexual activity was consistent among all participants, with two (16.7\%) cases self-reporting consistent condom use. Other risk factors for HIV transmission were also highly prevalent with eight $(66.6 \%)$ cases having STI symptoms, $10(83.3 \%)$ reporting substance abuse, nine $(75.0 \%)$ reporting sex work (SW) and one (33.3\%) selfreported man who has sex with men (MSM) [Table 2]. 
Table 1: Demographics, co-morbid illnesses and clinic visit frequency

\begin{tabular}{ll}
\hline Age $($ years; $\mathrm{n}=12)$ & $38.0(\mathrm{IQR} 32.5-49.25)$ \\
Gender $(\mathrm{n}=12)$ & $3: 9(\mathrm{M}: \mathrm{F})$ \\
Co-morbid illness $(\mathrm{n}=12)$ & \\
$\quad$ Syphilis & $1(8.3 \%)$ \\
$\quad$ Hepatitis C & $1(8.3 \%)$ \\
$\quad$ Diabetes/hypertension & $1(8.3 \%)$ \\
$\quad$ None & $9(75.0 \%)$ \\
Number of visits $(\mathrm{n}=12)$ & $4.5(\mathrm{IQR} 1.0-7.7)$ \\
\hline
\end{tabular}

Table 2: HIV transmission risk behaviour

\begin{tabular}{ll}
\hline Sexually active $(\mathrm{n}=12)$ & $12(100.0 \%)$ \\
Number of lifetime partners $(\mathrm{n}=7)$ & $30($ IQR $25.0-100.0)$ \\
Self-reported consistent condom use $(\mathrm{n}=12)$ & $2(16.7 \%)$ \\
STI symptoms $(\mathrm{n}=12)$ & $8(66.6 \%)$ \\
$\quad$ Urethral discharge & $2(16.7 \%)$ \\
$\quad$ Vaginal discharge & $6(50.0 \%)$ \\
Drug abuse $(\mathrm{n}=12)$ & $10(83.3 \%)$ \\
$\quad$ Marijuana & $7(58.3 \%)$ \\
Crack & $6(50.0 \%)$ \\
Cocaine & $3(25.0 \%)$ \\
Alcohol & $7(58.3 \%)$ \\
MSM (n=3) & $1(33.3 \%)$ \\
SW (n $=12)$ & $9(75.0 \%)$ \\
\hline
\end{tabular}

$\mathrm{MSM}=$ men who sleep with men, $\mathrm{SW}=$ sex work

The initial laboratory evaluation of the nine $(75.0 \%)$ cases who received blood testing revealed a mean CD4 count of 284.4 cells $/ \mathrm{mm}^{3}(95 \%$ CI 109.0, 459.8) [Table 3]. Of the nine cases who received CD4 testing, six (66.6\%) presented with counts below the minimum requirement for ART in Jamaica, a CD4 count of less than 350 cells $/ \mathrm{mm}^{3}$. In addition, high rates of anaemia, leukopenia and abnormal renal and hepatic function, at $80 \%, 40 \%, 75 \%$ and $50 \%$, respectively, were also reported (Table 3 ).

Table 3: Initial laboratory characteristics

Initial CD4 count cells $/ \mathrm{mm}^{3}(\mathrm{n}=9)$

Days between initial visit and initial CD4

$(\mathrm{n}=9)$

Anaemia $(\mathrm{n}=5)$

Leukopenia $(\mathrm{n}=5)$

Abnormal renal function $(\mathrm{n}=8)$

Abnormal hepatic function $(\mathrm{n}=8)$

Antiretroviral therapy was offered to all cases meeting eligibility criteria and accepted by five cases. All cases were offered standard non-nucleoside reverse transcriptase based first line highly active antiretroviral therapy (HAART) regimens. All five $(100 \%)$ cases reported inadequate adherence and none of them achieved virologic suppression. The median viral load after six or more months of ART was 100 488.0 (IQR 15023.2 - 291 867.0). There was no significant improvement in CD4 counts either with current CD4 counts of 174.0 cells $/ \mathrm{mm}^{3}(95 \%$ CI $47.5,395.5 ; p=0.9)$.
Table 4: Experience and response to antiretroviral therapy

\begin{tabular}{|c|c|}
\hline \multicolumn{2}{|l|}{ ART exposure $(\mathrm{n}=12)$} \\
\hline Yes & $7(58.3 \%)$ \\
\hline No & $5(41.7 \%)$ \\
\hline \multicolumn{2}{|l|}{ Regime type $(n=7)$} \\
\hline AZT/3TC/NVP & $1(14.3 \%)$ \\
\hline TDF/FTC/EFV & $3(42.8 \%)$ \\
\hline TDF/FTC/NVP & $1(14.3 \%)$ \\
\hline Unknown (previous exposure) & $2(28.6 \%)$ \\
\hline \multicolumn{2}{|l|}{ Self-reported ART adherence $(\mathrm{n}=5)$} \\
\hline Yes $(>95 \%$ adherence) & $0(0.0 \%)$ \\
\hline No & $5(100.0 \%)$ \\
\hline Current CD4 count cells $/ \mathrm{mm}^{3}(\mathrm{n}=4)$ & $174.0(95 \%$ CI 47.5-395.5) \\
\hline Current viral load copies/ml $(n=4)$ & 100488.0 (IQR 15 023.2-291 867.0) \\
\hline
\end{tabular}

ART: antiretroviral therapy, AZT: azidothymidine/zidovudine,

3TC: lamivudine, NVP: nevirapine, TDF: tenofovir disoproxil fumarate,

FTC: emtricitabine, EFV: efavirenz

\section{DISCUSSION}

Significant barriers in access to healthcare exist for the HIVinfected homeless people. As postulated by Maslow (6), basic needs such as food and shelter must first be addressed before specific issues surrounding routine healthcare can be adequately dealt with.

One of the primary activities of this collaborative project was locating the clients and providing transportation to the clinic. The difficulties of accessing this population are highlighted in the data as three $(25 \%)$ clients had only one visit to CHARES and had no laboratory evaluations completed. However, this was not seen throughout the population as there was an average of 4.5 visits (IQR 1.0-7.7), which is in keeping with general population guidelines for clinic attendance.

The project was successful in providing relatively rapid assessment of ART requirements as indicated by the length of time between the first visit and the first CD4 quantification of 14 days (IQR 7.0-38.5). The provision of treatment and care at the point of contact with this population can improve interaction with healthcare providers and the overall quality of care.

The initial CD4 counts reported in this population indicate the relatively late presentation to HIV treatment and care as $66.6 \%$ had counts less than 350 cells $/ \mathrm{mm}^{3}$, thereby satisfying the CD4 criteria for ART commencement. Additional laboratory features showed high rates of abnormality and emphasized the extensive healthcare requirements of this population, including extensive investigation and potentially, sub-specialty management.

Self-reported adherence is known to be a poor marker of adherence. However, it remains a useful tool with a high negative predictive value. None of the clients being offered ART met the adherence requirements for ART to be effective, greater than $95 \%$, exhibiting both low intermittent and complete non-adherence. Significant factors associated with poor adherence to HIV medication in the homeless population 
include depressive symptoms, substance abuse dis-orders and poor early adherence (7). Although rates of ad-herence have been notoriously low, homelessness should not have a negative influence in the decision to commence ART as poor adherence is not isolated to the homeless. Adherence to ART is a pervasive issue in HIV treatment and care pro-grammes. It has been documented in the general HIV popu-lation in Jamaica at self-reported rates of between $50 \%$ and $75 \%$ (8, 9). The concept of Direct Observation of Therapy (DOTS) as used in community-based tuberculosis therapy has proven to be instrumental and has also gained traction in the management of the HIV substance abuse population (10) as directly administered antiretroviral therapy (DAART). The use of pillboxes has also proven to improve adherence to $\mathrm{ART}$ and has the additional benefit of easy monitoring, for patients and providers (11). However, dependent on the specific environment, these should be maintained by case managers, in combination with DAART, in order to reduce the potential for stigmatization or theft.

As a result, there was a limited effect of ART on immunological markers. No significant differences in CD4 counts were observed between the initial CD4 count and current CD4 counts in cases receiving ART $(p=0.9)$. Virologic markers also indicated a limited effect of ART, with a median viral load count greater than 100000 copies $/ \mathrm{ml}$. This is indicative of a high risk for rapid progression to AIDS and an increased risk of HIV transmission (12).

There were also high rates of risk factors for onward HIV transmission identified. These include number of lifetime partners, 30 (IQR 25.0 - 100.0), low consistent condom use, two (16.7\%), high rates of STIs, substance abuse and sex work: eight (66.6\%), $10(83.3 \%)$ and nine (75.0\%), respectively. The incorporation of a combination prevention approach, as prescribed by UNAIDS (13), is an essential component of care and support and should be implemented.

The sample size of this study is small and is not reflective of the prevalence of homeless HIV-positive persons in Jamaica; the results cannot therefore be generalized. However, this report provides a brief insight into the difficulties of managing the HIV-infected homeless individual. The future direction of programmes developed to address this population should move toward an increasingly community- based intervention model. These should include elements of intensive case management, providing a comprehensive care approach to early screening, diagnosis and treatment of comorbid illnesses and addressing nutritional and housing needs, drug rehabilitation incorporating harm reduction methodologies and reintegration support.

\section{REFERENCES}

1. Bravo P, Edwards A, Rollnick S, Elwyn G. Tough decisions faced by people living with HIV: a literature review of psychosocial problems. AIDS Rev 2010; 12: 76-88.

2. Frank P. "The Preamble of the Constitution of the World Health Organization". Bulletin of the World Health Organization 2002; 80: 982.

3. National HIV/STI Programme, Monitoring and Evaluation Component. (Unpublished data). Kingston: National HIV/STI Programme.

4. National HIV/STI Programme, Monitoring and Evaluation Component. (Unpublished data). Kingston: National HIV/STI Programme.

5. Dowe G, Smikle M, Thesiger C, Williams EM. Blood borne sexually transmitted infections in patients presenting for substance abuse treatment in Jamaica. Sex Transm Dis 2001; 28: 266-9.

6. Maslow AH. A theory of human motivation. Psychological Review 1943; 50: 370-96.

7. Moss AR, Hahn JA, Perry S. Adherence to highly active antiretroviral therapy in the homeless population in San Francisco: a prospective study. Clin Infect Dis 2004; 39: 1190-8.

8. Harvey K, Carrington D, Duncan J, Figueroa JP, Hirschorn L, Manning $\mathrm{D}$ et al. Evaluation of adherence to highly active antiretroviral therapy in adults in Jamaica. West Indian Med J 2008; 57: 293-7.

9. Carrington D, Duncan J, Lindo JLM, Barton EN, Clarke TR, Barrow G et al. A baseline assessment of adherence to antiretroviral therapy among persons living with HIV/AIDS in Jamaica. West Indian Med J 2010; 59 (Suppl 4): 40

10. Lucas GM, Mullen BA, Weidle PJ, Hader S, McCaul ME, Moore MD. Directly administered antiretroviral therapy in methadone clinics is associated with improved HIV treatment outcomes, compared with outcomes among concurrent comparison groups. Clin Infect Dis 2006; 42: $1628-35$.

11. Petersen ML, Wang Y, van der Laan MJ, Guzman D, Riley E, Bangsberg D. Pillbox organizers are associated with improved adherence to HIV antiretroviral therapy and viral suppression - a marginal structural model analysis. Clin Infect Dis 2007; 45: 908-15.

12. Fideli US, Allen SA, Musonda R, Trask S, Hahn BH, Weiss $\mathrm{H}$ et al. Virologic and immunologic determinants of heterosexual transmission of human immunodeficiency virus type 1 in Africa. AIDS Res Hum Retroviruses 2001; 17: 901-10.

13. UNAIDS. Combination HIV prevention: tailoring and coordinating biomedical, behavioural and structural strategies to reduce new HIV infections. A UNAIDS discussion paper. Geneva: Joint United Nations Programme on HIV/AIDS; 2010. 